\title{
Saltwater Intrusion in Los Angeles Area Coastal Aquifers- the Marine Connection
}

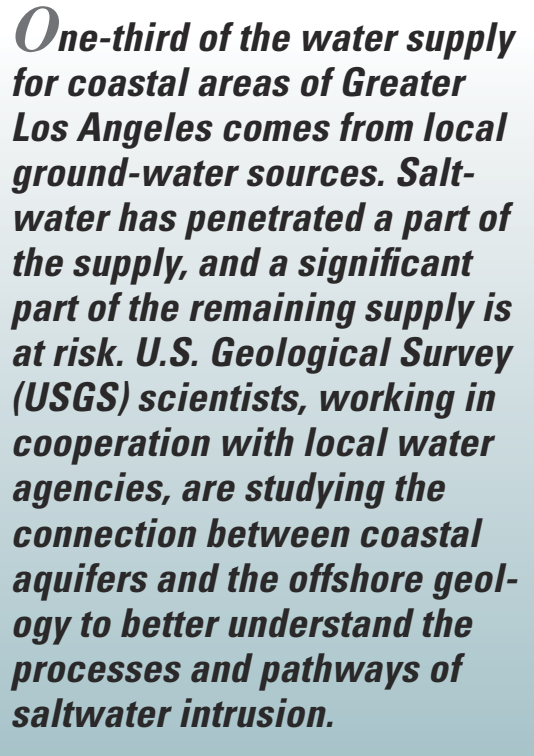

Saltwater from the Pacific Ocean is seeping into some Los Angeles Basin coastal aquifers and replacing freshwater. Without treatment, this ground water does not conform to drinking-water or agricultural standards.

This problem is significant because much of the water used by the nearly 10 million residents of Los Angeles County comes from ground-water sources. Although not all coastal aquifers in the region are at risk, the existing resources are vital and must be protected to maintain adequate supplies of potable water.

In the 1950's, construction began on the first of three "barriers" in an attempt to halt saltwater intrusion. Each barrier consists of a series of injection wells that essentially form a subsurface wall of freshwater designed to keep saltwater from penetrating further into aquifers. The barriers are only partly effective; saltwater continues to infiltrate in some areas.

New studies show that the ground-water geohydrology of the coastal aquifers

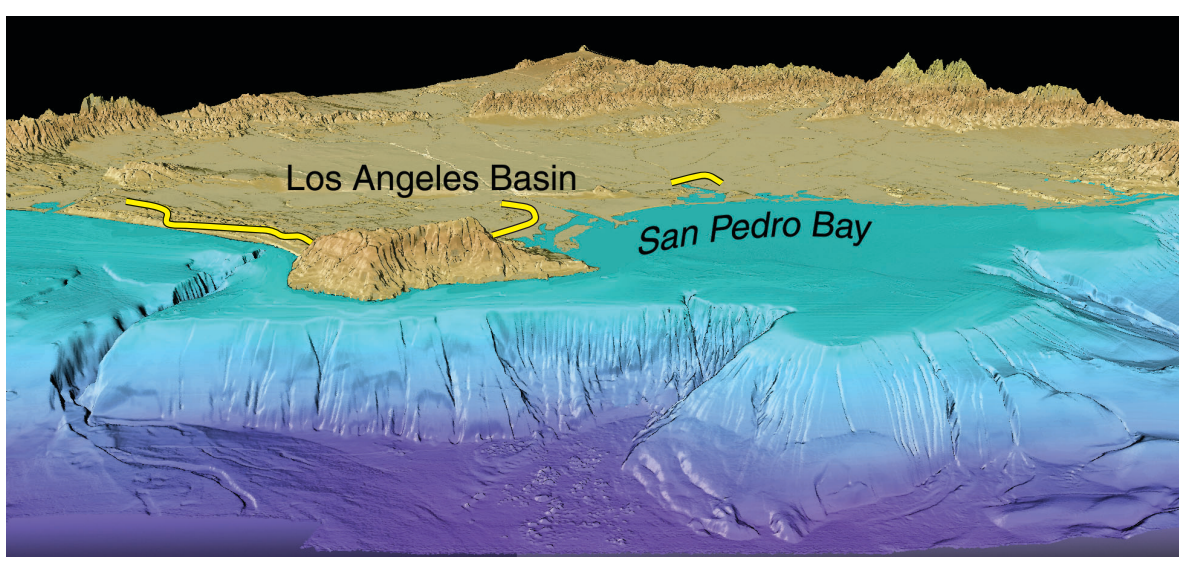

This computer-generated perspective view of the Greater Los Angeles region highlights the locations of "barriers" (shown in yellow) to saltwater intrusion into coastal aquifers. These barriers consist of freshwater injection wells. Because some saltwater continues to infiltrate into Los Angeles Basin aquifers, U.S. Geological Survey scientists are investigating the geology both onshore and offshore to better understand the pathways of saltwater intrusion. This image combines high-resolution offshore bathymetric data and onshore digital-elevation data. (Image produced by J.V. Gardner and P. Dartnell, U.S. Geological Survey.)

is more complex than previously imagined. U.S. Geological Survey (USGS) scientists, working in cooperation with the Water Replenishment District of Southern California and the Los Angeles County Department of Public Works, are expanding efforts to understand the geologic processes and fluid pathways that control saltwater intrusion.

Potential pathways for saltwater intrusion include hydraulic connection to aquifer beds exposed at the sea floor, flow along buried ancient stream channels, and flow through crushed rock in fault zones. The USGS and its cooperators are focusing their efforts on (1) conducting geologic and hydrologic studies on land and (2) surveying and mapping the sea floor near the coast.

To investigate the marine connection to saltwater intrusion in coastal areas of Greater Los Angeles, scientists are using a variety of techniques to study the geology offshore. An acoustic technique, known as reflection seismology, produces vertical profiles that provide information on the layering of strata in the subsurface and also on the geometry of geologic structures and buried erosional features, such as ancient stream channels. Another system uses laterally directed acoustic pulses to create detailed three-dimensional images of the sea floor. In addition to providing accurate

\section{POPULATION AND SALTWATER INTRUSION}

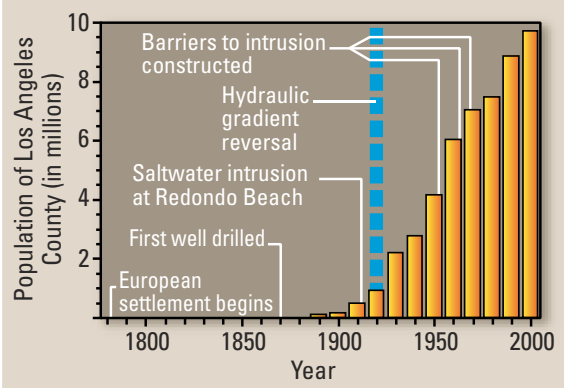

Saltwater intrusion in coastal aquifers of Los Angeles County is a result of increasing use of ground-water resources accompanying population growth. This diagram shows the growth of Los Angeles County's population and significant events in the history of ground-water usage. In the 1920's, the overall flow of coastal ground water reversed, leading to saltwater intrusion in some coastal aquifers. 


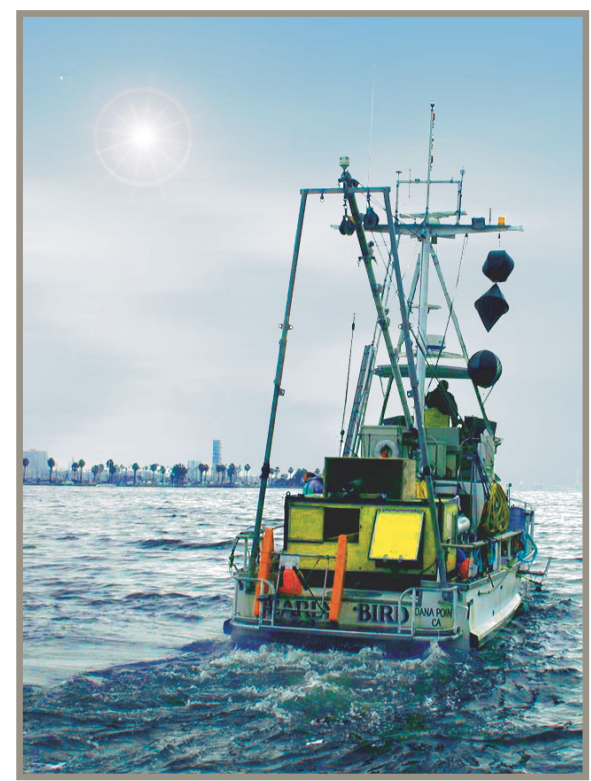

A research vessel chartered by the U.S. Geological Survey leaves port to collect data on submarine geology in Los Angeles and Long Beach Harbors. These data, obtained using an acoustic technique known as reflection seismology, are helping scientists understand the mechanisms of saltwater intrusion in coastal areas of Greater Los Angeles.

bathymetry, these images reveal features of the sea-floor morphology of both shallow shelf areas and deeper slopes and canyons (see perspective image on previous page).

Other techniques - such as deep continuous coring to collect sediment and porewater samples for analyses, as well as gravity modeling and fluid-flow modeling - provide additional new data for improving understanding of the geohydrology, sedimentology, seismic hazards, and tectonic evolution of strata in the Los Angeles Basin. By integrating new data sets and ideas with existing conceptual models, scientists are able to more accurately predict the fluid flow in ground-water systems and better understand the marine connection to saltwater intrusion in the region.

The efforts of the USGS and its cooperators in studying saltwater intrusion in coastal areas of the Los Angeles Basin are leading to a better understanding of how the groundwater supplies crucial to populous coastal regions can be managed and sustained. Such research is only part of the USGS efforts to protect people's lives and property from geologic and environmental hazards in the coastal zones of the United States.

Brian D. Edwards and Kevin R. Evans

SALTWATER INTRUSION INTO COASTAL AOUIFERS IN THE LOS ANGELES BASIN

In the late 1800's, water wells pumped by wind power were first used to tap into the ground water of the Los Angeles Basin (A). This technology provided abundant freshwater for residents of the parched coastal region, allowing for expansive growth of both population and agriculture. Increased pumping through the early 1900's caused potentiometric levels (the levels to which pressure in the aquifer would make water rise in cased wells) along the coastline to drop below sea level. As a result, a landward-directed pressure gradient caused saltwater to begin invading coastal aquifers as early as the 1920's (B).

In the 1950's, sets of closely spaced wells were drilled to inject high-quality freshwater into the ground, creating hydraulic pressure ridges or "barriers" to saltwater intrusion (C). Ideally, these barriers would stem the flow of saltwater into coastal aquifers. However, the barriers are not completely effective.

New studies by the U.S. Geological Survey and its cooperators show that the geology of the Los Angeles Basin is much more complex than originally conceived. A seismic profile from the Port of Long Beach (D) shows the complex geology of the area. The sediment layers, shown as different colors, provide many potential pathways for saltwater intrusion. By understanding this geology, scientists can better determine where and how fast water moves within the various beds of sediment both onshore and offshore.
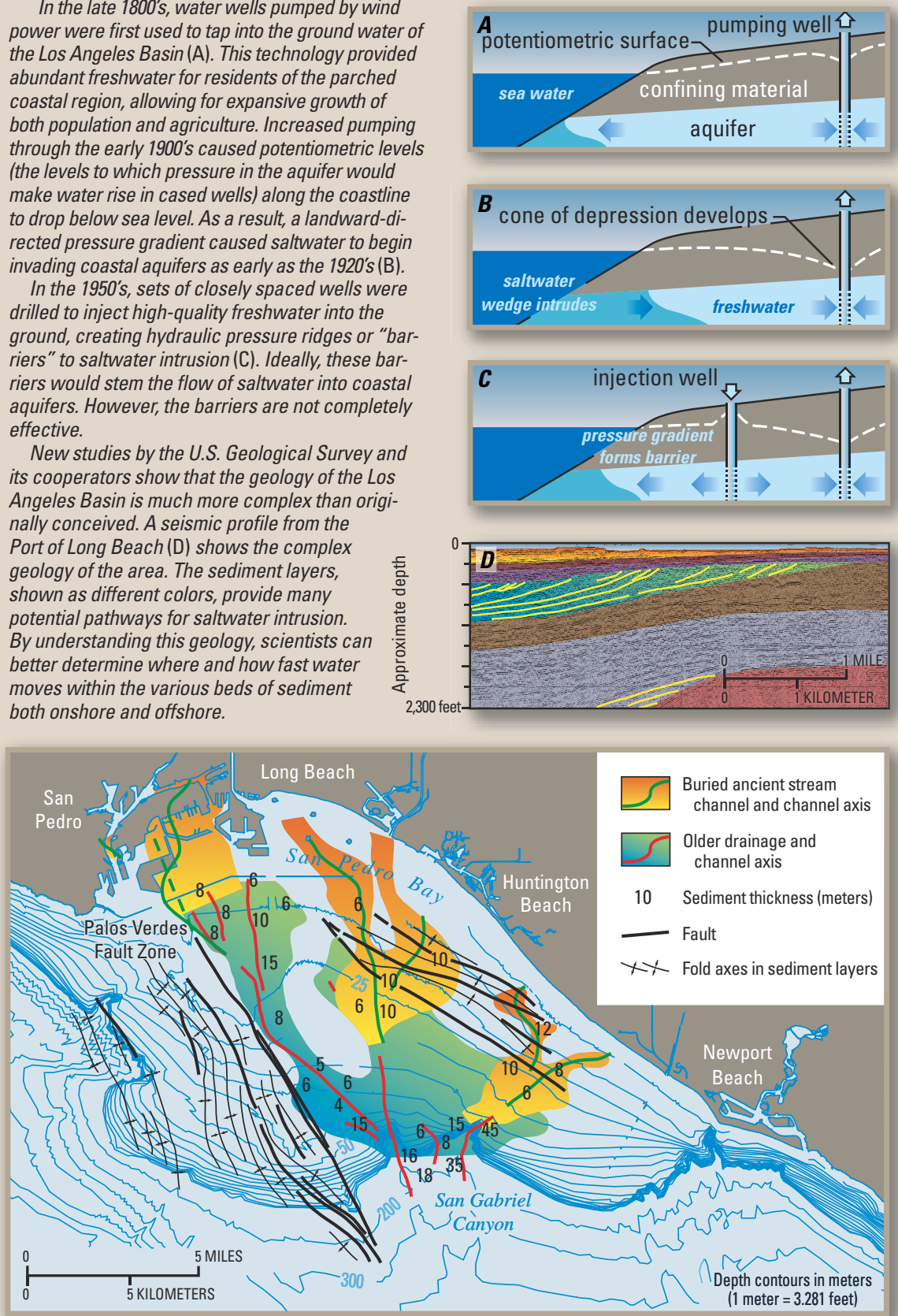

Bathymetric and high-resolution seismic data allow scientists to create accurate maps of the offshore Los Angeles region. This map shows the San Gabriel Canyon, faults, folds, and sediment-filled ancient stream channels that cross the offshore shelf areas in the region. The ancient stream channels and faults are potential pathways for the infiltration of saltwater into coastal aquifers. New studies focus on mapping the seaward extent of coastal aquifers below the sea floor, locating underwater rock outcrops, and understanding the physical properties and porewater chemistry of sediments.

Edited by

James W. Hendley II and Peter H. Stauffer Graphic design by

Kevin R. Evans, Rudolph R. Contreras, Sara Boore, and Susan Mayfield

\section{COOPERATING ORGANIZATIONS}

Water Replenishment District of Southern California Los Angeles County Department of Public Works
For more information contact: U.S. Geological Survey 345 Middlefield Road, MS-999 Menlo Park, CA 94025 (650) 329-5042

http://walrus.wr.usgs.gov

This fact sheet and any updates to it are available online at: http://geopubs.wr.usgs.gov/fact-sheet/fs030-02/ 